\title{
Combining laser capture microdissection with quantitative real-time PCR: Effects of tissue manipulation on RNA quality and gene expression
}

\author{
Ilan A. Kerman*, Bradley J. Buck, Simon J. Evans, Huda Akil, Stanley J. Watson \\ Molecular and Behavioral Neuroscience Institute, Department of Psychiatry, University of Michigan, 205 Zina Pitcher Place, Ann Arbor, MI 48109, USA
}

Received 23 December 2004; received in revised form 28 August 2005; accepted 13 October 2005

\begin{abstract}
Laser capture microdissection (LCM) is increasingly being used in quantitative gene expression studies of the nervous system. The current study aimed at determining the impact of various tissue manipulations on the integrity of extracted RNA in LCM studies. Our data indicate that various tissue preparation strategies prior to microdissection may decrease RNA quality by as much as $25 \%$, thus affecting expression profiles of some genes. To circumvent this problem, we developed a strategy for reverse transcriptase real-time PCR that has considerable sensitivity and can be used to calculate relative changes in gene expression. This approach was validated in subregions of the rat cerebellum. Accordingly, expression of glial gene markers - myelin-associated glycoprotein and proteolipid protein 1-was found 70-160-fold higher in the white matter layer of the cerebellar cortex as compared to the neuron-enriched granular layer. In contrast, expression of a specific neuronal maker, neuron-specific enolase, was found seven-fold higher in the granular layer, as compared to the white matter layer. Furthermore, this approach had high sensitivity and specificity as we were able to detect a $38 \%$ decrease in the expression of neuron-specific enolase without a change in the expression of glial markers following administration of the neurotoxin, ibotenic acid. These results demonstrate feasibility of performing accurate semi-quantitative gene expression analyses in LCM samples.
\end{abstract}

(C) 2005 Elsevier B.V. All rights reserved.

Keywords: Rat; Brain; RNA; qRT-PCR; Laser capture microdissection; Gene expression

\section{Introduction}

Laser capture microdissection (LCM) was originally developed at the NIH for dissection of small samples and specific cell populations from cancer specimens (Emmert-Buck et al., 1996). It has subsequently been used for DNA and mRNA expression studies in a wide variety of tissues, including colon, stomach, breast, prostate, kidney, and the retina (Aoyagi et al., 2003; Haque et al., 2002; Luzzi et al., 2003; Murakami et al., 2000; Shi et al., 2003). More recent investigations have focused on applying LCM to the study of the central nervous system. These have included genome-wide gene expression analyses using DNA microarrays, as well as expression analyses of individual genes using reverse-transcriptase polymerase chain reaction (RT-PCR) (Jin et al., 1999; Kamme et al., 2003; Lu et al., 2004; Mutsuga et al., 2004; Torres-Munoz et al., 2001; Ye et al., 2003).

Two different technologies are currently available for LCM. The first approach uses a low-power laser to melt adhesive plas-

\footnotetext{
* Corresponding author. Tel.: +1 734936 3651; fax: +1 2082755434

E-mail address: kerman@umich.edu (I.A. Kerman).
}

tic onto the tissue of interest, which is then lifted off the slide using an apposed cap (Emmert-Buck et al., 1996). This method has been commercialized by Arcturus with the production of the PixCell and the AutoPix instruments. An alternative method employs a high-power cutting laser, which cuts around the tissue of interest. The specimen is then collected off a polymer-coated slide by a lifting laser. Instruments utilizing this approach are currently manufactured by PALM and Leica (Burbach et al., 2003; Roehrl et al., 1997). An advantage of the first method is that it does not require specially coated slides, as does the latter.

Recent reports have combined microdissection, utilizing both LCM platforms, with quantitative real-time RT-PCR (qRT-PCR) (Burbach et al., 2003, 2004; Heath et al., 2002; Prosniak et al., 2003; Vincent et al., 2002). However, questions remain as to the quality of extracted RNA in these studies, and how it may be affected by experimental manipulations. Furthermore, it has not been established which RNA quality measure is best suited for samples with small amounts of total RNA. In order for this methodology to be used effectively in the study of the brain, the following issues must be addressed: (a) determination of the quality of RNA extracted from samples collected with LCM; (b) determination of how manipulations involved in sample collec- 


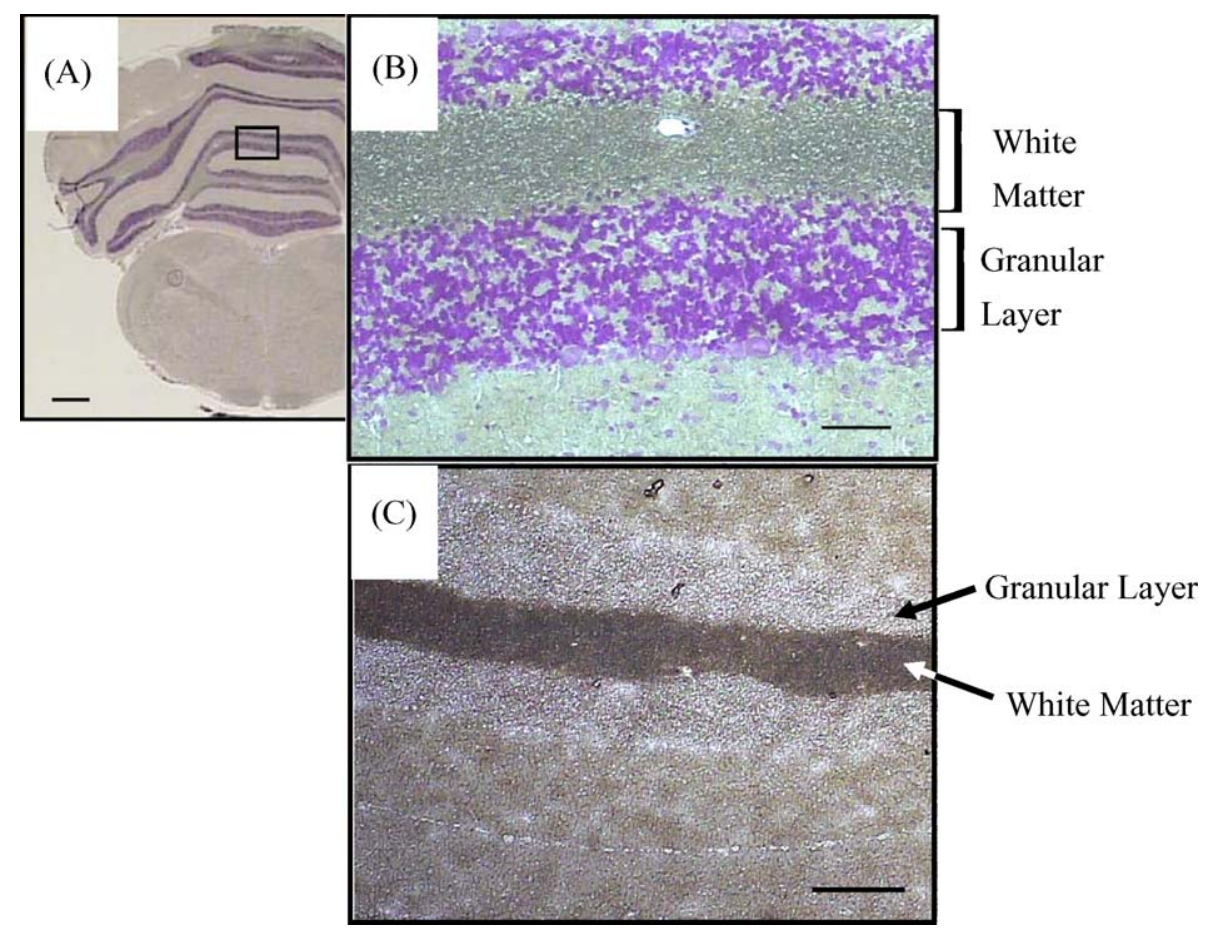

Fig. 1. Neuroanatomical organization of the cerebellum. Note the laminar organization of cerebellar cortex as shown in a cresyl violet-stained tissue section (A). Note the clear distinction between the white matter layer and the granular layer observed at high power (B). Based on their appearance and relationship to each other different cerebellar layers can also be resolved in non-stained tissue (C). Box in (A) is shown at high power in (B). Scale bars: $1 \mathrm{~mm}(\mathrm{~A}), 100 \mu \mathrm{m}(\mathrm{B})$, and $250 \mu \mathrm{m}$ (C).

tion affect RNA quality; (c) which RNA quality measure is best suited for evaluating small amounts of total RNA; (d) how do RNA quality and yield impact qRT-PCR results; (e) what is the sensitivity of this approach?

To address these issues we quantified RNA quality using three different parameters and have correlated changes in RNA quality with the outcome of qRT-PCR experiments. We have also validated this approach in the cerebellum, which was chosen because of its cytoarchitectonic organization with clearly separated layers enriched with either neurons or glia (see Fig. 1). Furthermore, to determine the sensitivity of this technique we examined alterations in gene expression in response to a neurotoxic lesion of the cerebellum.

\section{Materials and methods}

All of the procedures regarding animal use in this study conformed to the Guide for the Care and Use of Laboratory Animals (1996, National Academy of Sciences) and were approved by the University Committee on Use and Care of Animals at the University of Michigan.

\subsection{Tissue preparation and collection}

Tissue used in this study was obtained from a total of eight adult Sprague-Dawley rats purchased from Charles River Laboratories (Wilmington, MA). The animals were rapidly decapitated using a guillotine, their brains were harvested, flash frozen in 2-methylbutane at $-30^{\circ} \mathrm{C}$, and then stored at $-80^{\circ} \mathrm{C}$ until further processing. At the time of sectioning, caudal brainstem and cerebellum were dissected, the tissue block was mounted on a cryostat stage and then embedded in M-1 embedding matrix (Thermo Shandon, Pittsburgh, PA). Tissue was sectioned in the coronal plane on a cryostat at $-20{ }^{\circ} \mathrm{C}$ at a thickness of $10 \mu \mathrm{m}$. Immediately after sectioning, each tissue section was thaw mounted by apposing the slide directly onto the cryostat stage. Sections were mounted either on poly-lysine coated slides or onto charged slides (Arcturus, Mountain View, CA). Brains were sectioned in three different ways as follows: Set 1 -a series of adjacent sections were mounted on 10 different slides, with subsequent sections mounted next to the preceding sections on each slide. A total of four sections per slide were collected, with each section separated by $100 \mu \mathrm{m}$ and sections 1 and 4 separated by $400 \mu \mathrm{m}$. Set 2 was prepared similarly to Set 1 except each slide contained two sections, which were separated by $100 \mu \mathrm{m}$. Slides in Sets 1 and 2 were kept at room temperature until they contained either four or two sections, after which time they were maintained at $-20^{\circ} \mathrm{C}$. Set 3 - only one section was mounted on each slide, which was immediately put on dry ice. This approach yielded groups of sections that were exposed to ambient air during sectioning for an average of $0,90,110,180,220,330$, and $420 \mathrm{~s}$. Following tissue sectioning slides were stored at $-80^{\circ} \mathrm{C}$.

\subsection{Ibotenic acid injections}

In order to determine the sensitivity of qRT-PCR in laser capture microdissected tissue, ibotenic acid (IBO) was injected into the cerebellum of three rats. IBO is a neurotoxin which selectively destroys neurons while sparing the fibers of passage (Inglis and Semba, 1997), thus it was used to selectively destroy 
granular cells in the cerebellar cortex. IBO was purchased from Sigma-Aldrich (http://www.sigmaaldrich.com/) and was dissolved to $10 \mu \mathrm{g} / \mu \mathrm{l}$ in PBS alkalinized with $1 \mathrm{M} \mathrm{NaOH}$; final $\mathrm{pH}$ was adjusted to 7.3 with $25 \% \mathrm{HCl}$.

Anesthesia was induced with $5 \%$ isofluorane delivered in $1-1.5 \mathrm{l} / \mathrm{min}$ of $\mathrm{O}_{2}$ and then maintained with $1-2 \%$ in $1-1.5 \mathrm{l} / \mathrm{min}$ of $\mathrm{O}_{2}$. Once the surgical plane of anesthesia was achieved, as evidenced by the absence of withdrawal to tail and foot pinch stimuli, rats were placed in a stereotaxic frame with the incisor bar set at $-3.3 \mathrm{~mm}$. Prior to incisions, the overlying skull was shaved and disinfected with iodine. Pressure injections were made through a glass micropipette connected to a Hamilton syringe via PE tubing. A total volume of $500 \mathrm{nl}$ was injected over 5-10 min period into the left cerebellar hemisphere at the following coordinates: $4.0 \mathrm{~mm}$ caudal to lambda, $2.8 \mathrm{~mm}$ lateral to the midline at a depth of $4.3 \mathrm{~mm}$ from the skull surface. Following a 24-h survival period the animals were sacrificed, and their brains were extracted and processed in the same manner as described above.

\subsection{Tissue staining}

Slides were removed from $-80^{\circ} \mathrm{C}$ storage and were thawed at room temperature for $30 \mathrm{~s}$. They were then placed in $75 \%$ ethanol for $30 \mathrm{~s}$, and then were washed in distilled water for $30 \mathrm{~s}$. Tissue sections were stained either with $1 \%$ cresyl violet containing $1 \%$ glacial acetic acid solution, or with $1 \%$ neutral red dissolved in $4 \%$ sodium acetate buffer $(\mathrm{pH} 4.8)$. Both staining solutions also contained 1.6 units/ $\mu$ l of RNase inhibitor (GeneChoice, Frederick, MD). Cresyl violet or neutral red solution was applied directly onto the section, which was outlined by a hydrophobic slide marker (Pap Pen, Research Products International, www.rpicorp.com). Slides were then washed in distilled water for $30 \mathrm{~s}$ and dehydrated in graded alcohols $-30 \mathrm{~s}$ in $75 \%$ ethanol, $30 \mathrm{~s}$ in $95 \%$ ethanol, and $30 \mathrm{~s}$ twice in $100 \%$ ethanol. Some sections remained unstained, and in those cases the preparation was the same except for the staining step. All aqueous reagents were prepared with diethylpyrocarbonate (DEPC) treated water or were certified as RNase-free and purchased from Arcturus (Mountain View, CA). To complete the dehydration, slides were placed in xylene for $10 \mathrm{~min}$ and then air-dried in the hood for $\geq 5$ min prior to microdissection.

\subsection{Laser capture microdissection and tissue scrapes}

LCM was performed using the AutoPix instrument (Arcturus), which was equipped with an inverted base microscope system with $4 \times, 10 \times$, and $20 \times$ objectives from Olympus. Microdissections were performed under $4 \times$ objective using CapSure LCM macro caps (Arcturus). Laser settings were chosen to maximize the size of the laser spot without contaminating the sample with non-target tissue. Settings ranged from 55 to $100 \mathrm{~mW}$ in power, $1500-2300 \mathrm{~ms}$ in duration, and $200-250 \mathrm{mV}$ in intensity. The offset and overlap were typically $20-65 \%$. Efficiency of microdissection was evaluated by examining the cap after capture, and by examining the tissue before and after lift- ing off the cap (see Fig. 2). In most instances, a separate cap was used for each microdissected area so that a single captured area was placed on each cap. Following tissue collection, the cap was incubated in $50 \mu \mathrm{m}$ of PicoPure RNA extraction buffer (Arcturus) at $42^{\circ} \mathrm{C}$. After a $30 \mathrm{~min}$ incubation period, extracted RNA was spun into a $0.5 \mathrm{ml}$ plastic tube (from Arcturus or GeneAmp reaction tube from Applied Biosystems, www.appliedbiosystems.com) and frozen at $-80{ }^{\circ} \mathrm{C}$.

Tissue scrapes were performed using a clean scalpel blade, which was used to scrape an entire tissue section at room temperature into $100 \mu \mathrm{l}$ of PicoPure extraction buffer. The sample was briefly spun down prior to a $30 \mathrm{~min}$ incubation at $42^{\circ} \mathrm{C}$, and extracted RNA was frozen at $-80^{\circ} \mathrm{C}$.

\subsection{RNA isolation}

RNA isolation was performed using the PicoPure RNA isolation kit (Arcturus). Following RNA extraction, each sample was pipetted onto a purification column pre-treated with $250 \mu \mathrm{l}$ of conditioning buffer. In some cases in order to increase RNA yield, RNA extracted from two separate caps was combined by pipetting both samples onto the same purification column. Following application of Wash Buffer 1, the column was treated with $40 \mu$ l of RNase-Free DNase incubation mix (Qiagen, Valencia, CA) for $15 \mathrm{~min}$. The column was then washed with Wash Buffers 1 and 2, and total RNA was eluted in $11 \mu$ l (LCM samples) or $20 \mu \mathrm{l}$ (tissue scrapes) of Elution Buffer. Isolated RNA was then frozen at $-80^{\circ} \mathrm{C}$ until further processing. Stored RNA was reverse transcribed within 2 weeks and used for qRTPCR experiments within three months of extraction. To monitor possible degradation of isolated RNA from LCM samples, we prepared a quality control mix of high quality RNA, which was aliquoted into separate volumes and frozen at $-80^{\circ} \mathrm{C}$. Regular examinations of RNA quality and concentration of this mix on the Agilent 2100 BioAnalyzer revealed no decline in either of these parameters during the course of our studies, indicating stability of isolated RNA.

\subsection{RNA quality control}

The quality and quantity of isolated total RNA were evaluated using the 2100 BioAnalyzer (Agilent Technologies, Palo Alto, CA). One microliter from each isolated RNA sample was analyzed with RNA 6000 Pico Assay employing RNA Pico LabChips (Agilent Technologies). The resultant electropherograms were used to determine RNA integrity and concentration.

Three different measures were used to assess RNA quality including: (1) 28s/18s rRNA subunit ratio (28s/18s), which was calculated by dividing the area under the $28 \mathrm{~s}$ peak by that of the $18 \mathrm{~s}$ peak; (2) $18 \mathrm{~s} /$ baseline peak ratio (18s/baseline), which was calculated by dividing the height of the $18 \mathrm{~s}$ peak by the height of the highest baseline peak preceding the $18 \mathrm{~s}$ peak (see Fig. 3); (3) RNA integrity number (RIN), which is based on a proprietary Agilent Technologies algorithm (Mueller et al., 2004) and is calculated by the 2100 Expert software (Agilent Technologies). 


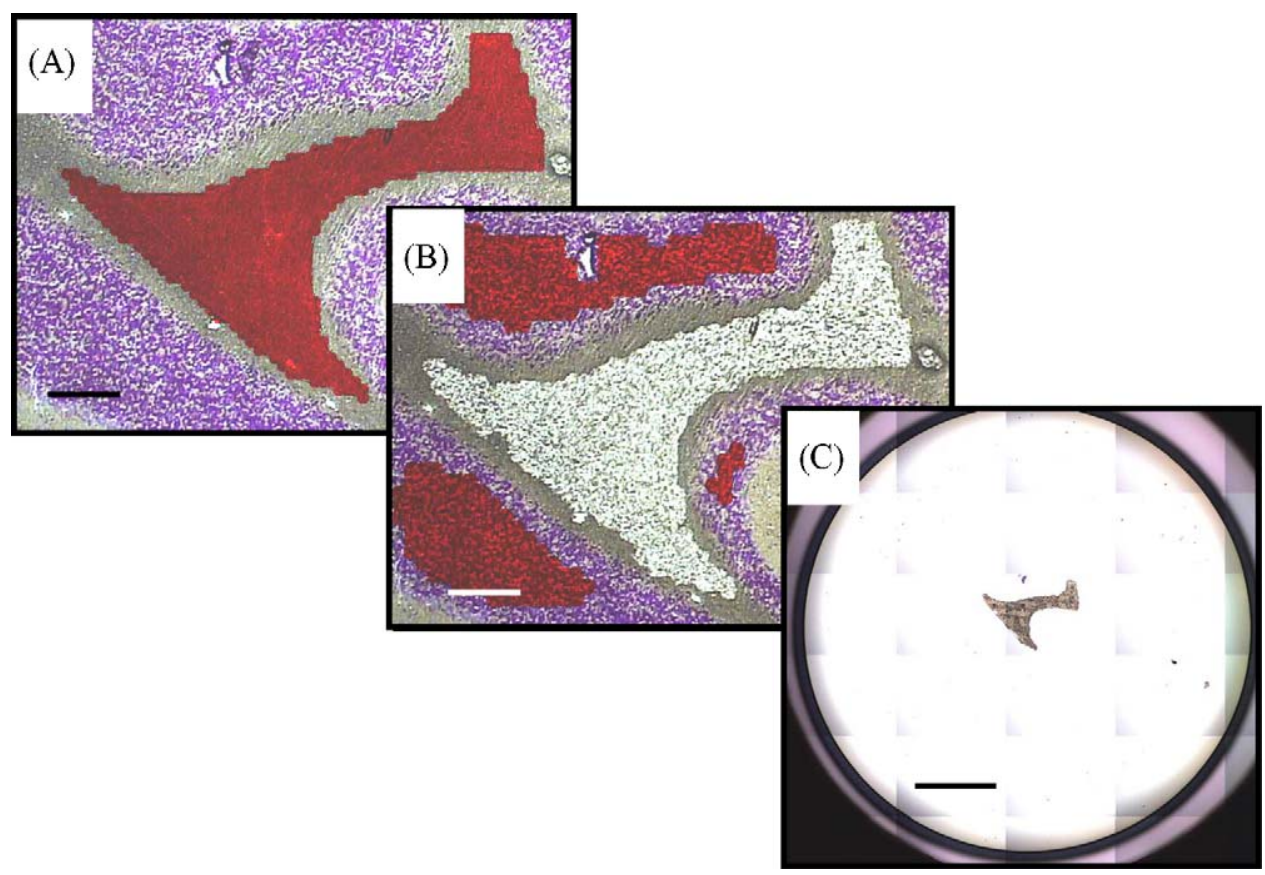

Fig. 2. Illustration of the LCM process: an image of cerebellar cortex was digitized at high magnification, and the white matter layer was outlined in red (A). The cap was then apposed to the tissue and the laser was fired through the cap to melt off the plastic. The cap was then lifted to harvest the tissue, and the section examined to ensure that the sample was collected (B). The cap was also examined to ensure appropriate lifting of the specimen (C). Scale bars: $500 \mu \mathrm{m}$ (A and B), and $3 \mathrm{~mm}(\mathrm{C})$.

\section{7. $c D N A$ synthesis}

First-strand cDNA synthesis was performed by using an EndoFree RT kit (Ambion, Austin, TX) according to manufacturer's directions. Briefly, $7 \mu l$ of isolated RNA was mixed with $1 \mu \mathrm{l}$ of $10 \mu \mathrm{M}$ anchored oligo(dT) primer, and the mix was denatured at $70{ }^{\circ} \mathrm{C}$ for $5 \mathrm{~min}$. This mixture was allowed

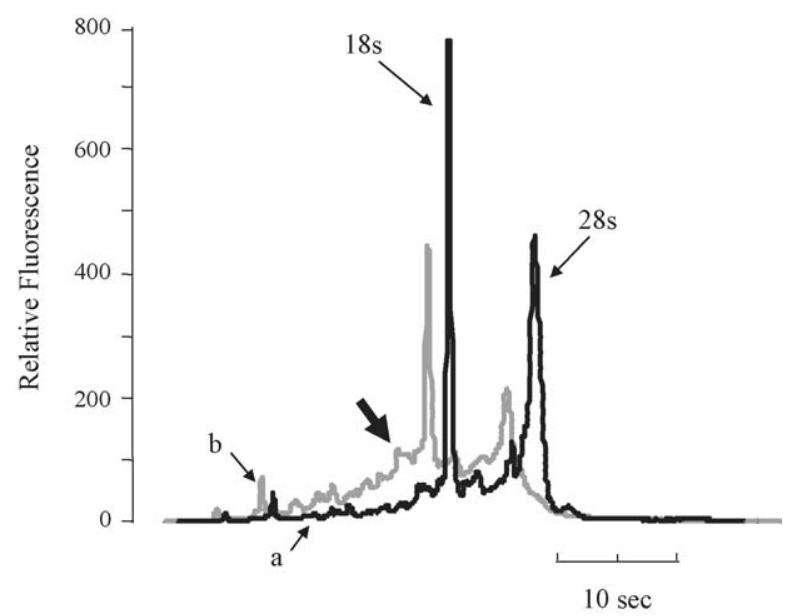

Fig. 3. Electropherogram of RNA isolated from tissue scrapes of sections that were mounted either one (trace a) or four (b) per slide. Electropherogram (b) was obtained from a section that was also stained with neutral red, while trace (a) was recorded from an unstained section. Note a decrease in the relative ratio of $28 \mathrm{~s} / 18 \mathrm{~s}$ rRNA from (a) to (b), as well as a decrease in the ratio of $18 \mathrm{~s} / \mathrm{highest}$ peak of preceding baseline (shown with heavy arrow in $b$ ). RNA quality measures for these samples were as follows: $\mathrm{RIN}=8.6,28 \mathrm{~s} / 18 \mathrm{~s}=1.20,18 \mathrm{~s} / \mathrm{baseline}=13.7$ (a), and RIN $=6.1,28 \mathrm{~s} / 18 \mathrm{~s}=0.70,18 \mathrm{~s} /$ baseline $=3.77$ (b) . to equilibrate at $49{ }^{\circ} \mathrm{C}$ for $5 \mathrm{~min}$. It was then combined with $1 \mu \mathrm{l}$ of reverse transcriptase and a mix of dNTPs, final concentration of $250 \mathrm{nM}$, RT buffer, and 10 units of RNase inhibitor, that was incubated at $49^{\circ} \mathrm{C}$ for $5 \mathrm{~min}$ in a separate tube before it was added to the RNA-primer mix. The synthesis reaction was allowed to proceed for $2 \mathrm{~h}$ at $49^{\circ} \mathrm{C}$, after which time cDNA was either stored at $-20^{\circ} \mathrm{C}$ or used immediately for PCR.

\subsection{PCR primer design}

Genomic DNA and mRNA sequences were downloaded from NCBI LocusLink at http://www.ncbi.nlm.nih.gov/LocusLink/ for the following genes: cyclophilin A (Ppia), glyceraldehyde3-phosphate dehydrogenase (Gapd), myelin-associated glycoprotein (Mag), neurofilament light chain (Nfl), neuron-specific enolase (Eno2), proteolipid protein 1 (Plp), and small nuclear ribonucleoparticle-associated protein (snRNP). Locations of introns and exons were mapped using the algorithm of Pearson et al. (1997) from GeneStream at http://xylian.igh.cnrs.fr/. For each gene of interest PCR primer pairs were designed to span the $3^{\prime}$-most intron and to generate an amplicon that was shared by all of the known splice variants. All primer sets were designed to generate a single amplicon, except for the Mag primer pair. These primers were designed to span three alternatively spliced exons at the $3^{\prime}$ end of the transcript, thus amplifying two splice variants 176 and $221 \mathrm{bp}$ in size (Table 1). Secondary structure was minimized for each amplicon using DNA Mfold (Zuker, 2003) (http://www.bioinfo.rpi.edu/applications/mfold/), and primers were designed against regions lacking predicted secondary structure. 
Table 1

PCR primers used in the current study

\begin{tabular}{|c|c|c|c|c|c|}
\hline Gene & Symbol & Accession number & Primers $\left(5^{\prime}, 3^{\prime}\right)$ & $T_{\mathrm{m}}\left({ }^{\circ} \mathrm{C}\right)$ & Product size (bp) \\
\hline Cyclophilin A & Ppia & NM_017101 & $\begin{array}{l}\text { ACAGGTCCTGGCATCTTGTC } \\
\text { GTTGTCCACAGTCGGAGATG }\end{array}$ & $\begin{array}{l}60.1 \\
59.1\end{array}$ & 214 \\
\hline Glyceraldehyde-3-phosphate dehydrogenase & Gapd & NM_017008 & $\begin{array}{l}\text { CTCCCATTCTTCCACCTTTG } \\
\text { AGGGAGATGC TC AGTGTTGG }\end{array}$ & $\begin{array}{l}59.5 \\
60.3\end{array}$ & 250 \\
\hline Myelin-associated glycoprotein & Mag & NM_017190 & $\begin{array}{l}\text { ATTCCGAATCTCTGGAGCAC } \\
\text { ACTCAGCCAGCTCCTCTGTC }\end{array}$ & $\begin{array}{l}59.2 \\
59.7\end{array}$ & 176 and 221 \\
\hline Neurofilament light chain & $\mathrm{Nfl}$ & NM_031783 & $\begin{array}{l}\text { GAGGAAGAGGAAGGTGCTGA } \\
\text { TC AAC TGGTTGGTTTGGTGA }\end{array}$ & $\begin{array}{l}60.0 \\
60.0\end{array}$ & 242 \\
\hline Neuron-specific enolase & Eno2 & NM_139325 & $\begin{array}{l}\text { ACGTCTGGCGAAGTACAACC } \\
\text { GTCGGGACAGCAAGAAAGAG }\end{array}$ & $\begin{array}{l}60.2 \\
60\end{array}$ & 167 \\
\hline Proteolipid protein 1 & Plp & NM_030990 & $\begin{array}{l}\text { CCAAATGACCTTCCACCTGT } \\
\text { ATCAGTGGCAAAGGCAGAGT }\end{array}$ & $\begin{array}{l}59.8 \\
59.9\end{array}$ & 297 \\
\hline Small nuclear ribonucleoparticle-associated protein & snRNP & NM_031117 & $\begin{array}{l}\text { AGGAATGAGACCCССТССТC } \\
\text { AAGAGGGGTCAAAAGCTTGC }\end{array}$ & $\begin{array}{l}61.7 \\
60.7\end{array}$ & 155 \\
\hline
\end{tabular}

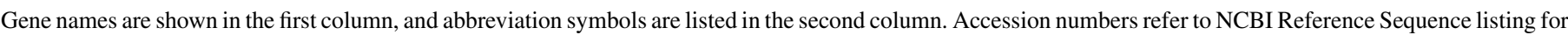

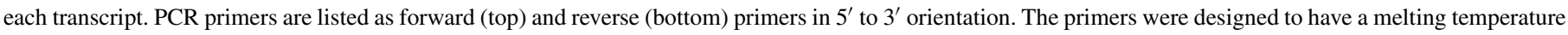
$\left(T_{\mathrm{m}}\right)$ near $60^{\circ} \mathrm{C}$, and amplicons ranged from 155 to $297 \mathrm{bp}$ in size.

\section{9. $P C R$}

Total volume for each real-time PCR was $20 \mu \mathrm{l}$, which included $1 \mu \mathrm{l}$ of cDNA, forward and reverse primers at a final concentration of $450 \mathrm{nM}$, and $10 \mu \mathrm{l}$ of iQ SYBR Green Supermix (Bio-Rad Laboratories, Hercules, CA), containing 50 units/ml iTaq/DNA polymerase, $6 \mathrm{mM} \mathrm{MgCl}_{2}, 0.4 \mathrm{mM}$ of each dNTP, and $20 \mathrm{nM}$ fluorescein. All amplifications and fluorescence quantifications were performed in real time on a Bio-Rad iCycler (Bio-Rad), using a FAM-490 or SYBR-488 detection protocol, at a peak excitation wavelength of $490 \mathrm{~nm}$ and peak emission wavelength of $530 \mathrm{~nm}$. To minimize amplification of non-specific products, a hot-start PCR protocol was employed as follows: denature at $95^{\circ} \mathrm{C}$ for $1 \mathrm{~min}$ and $45 \mathrm{~s}$, followed by 10 cycles of denaturing at $95^{\circ} \mathrm{C}$ for $15 \mathrm{~s}$, annealing at $65-60{ }^{\circ} \mathrm{C}$ for $15 \mathrm{~s}$, extension at $72{ }^{\circ} \mathrm{C}$ for $15 \mathrm{~s}$. Annealing temperature was decreased at each step of the cycle by $0.5^{\circ} \mathrm{C}$ from a maximum of $65^{\circ} \mathrm{C}$ to the final temperature of $60^{\circ} \mathrm{C}$. This was followed by 35 cycles of denaturing at $95^{\circ} \mathrm{C}$ for $15 \mathrm{~s}$, annealing at $60^{\circ} \mathrm{C}$ for $15 \mathrm{~s}$, extension at $72^{\circ} \mathrm{C}$ for $15 \mathrm{~s}$. Following each extension step, primer dimers were denatured by increasing the temperature to $83^{\circ} \mathrm{C}$ for $30 \mathrm{~s}$, and fluorescence was quantified. This cycling was followed by a final extension step at $72{ }^{\circ} \mathrm{C}$ for $5 \mathrm{~min}$.

Following amplification, PCR products were denatured by sequential increases in temperature from 72 to $95^{\circ} \mathrm{C}$ in $0.5^{\circ} \mathrm{C}$ increments. At each step the temperature was held constant for $10 \mathrm{~s}$, during which time fluorescence was quantified. Presence of specific amplification products was confirmed by the single peak on the melting curve, plotted as the negative derivative of fluorescence as a function of temperature (see Fig. 4B). Specificity of amplification was verified by the presence of DNA of appropriate size on a $2 \%$ agarose gel visualized with ethidium bromide, and by the absence of amplified DNA in no template controls. Each band was then cut out from the
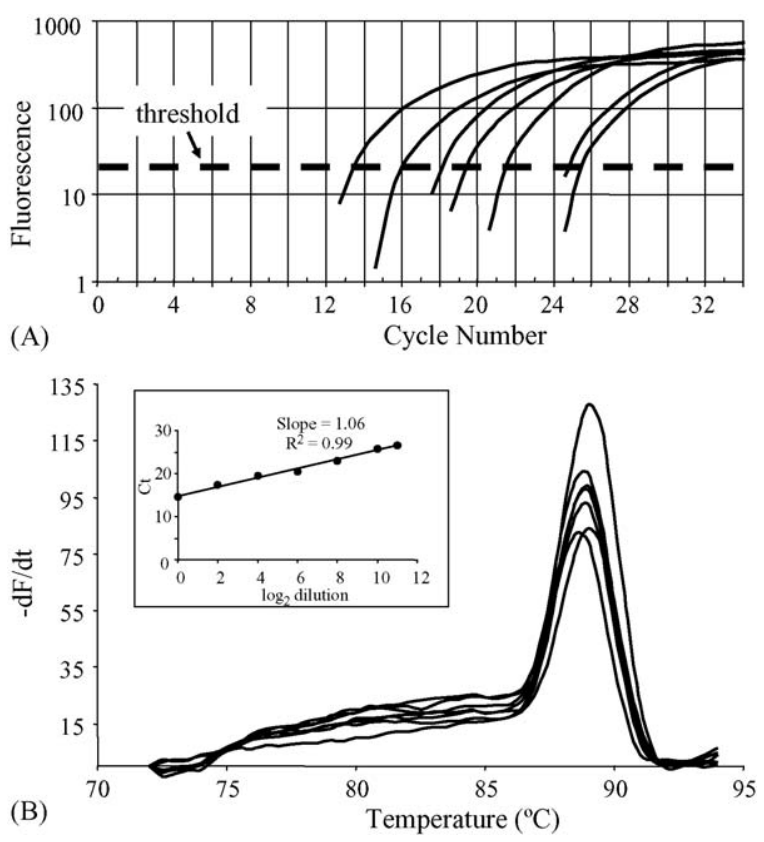

Fig. 4. Quantitative real-time PCR for Mag using input RNA from a tissue scrape. Following reverse transcription, cDNA was serially diluted at 1:4 and 1:2 dilutions. Assuming complete reverse transcription efficiency, cDNA concentrations were as follows: $2600,650,162.5,40.6,10,2.54$, and $1.27 \mathrm{pg} / \mu \mathrm{l}$. To quantify relative template concentration, $\log _{10}$ of fluorescence was plotted as a function of cycle number, and a threshold was set during exponential phase of amplification (A). $C_{\mathrm{t}}$ was defined as a point at which each amplification curve intersected the threshold (see text for details). To assess amplification efficiency and the limit of detection of this approach, $C_{\mathrm{t}}$ was plotted as a function of $\log _{2}$ dilution factor (inset). This plot revealed amplification efficiency close to $100 \%$ (slope 1.06) and the limit of detection of $1.27 \mathrm{pg} / \mu \mathrm{l}$ or lower (right-most point on the plot, representing the most dilute sample). Specificity of amplification was assessed with a melt study. For each amplification reaction, only a single peak was present on the melt curve (B), indicating an absence of non-specific amplification and primer-dimer formation. Absence of non-specific amplicons was also confirmed with gel electrophoresis (data not shown). 
gel and the DNA extracted using QIAquick gel extraction kit from Qiagen (Valencia, CA). Extracted DNA was sequenced using automated deoxynucleotide sequencing at the University of Michigan DNA sequencing core. Amplicon specificity was confirmed with NCBI's Basic Local Alignment Search Tool (BLAST) at http://www.ncbi.nlm.nih.gov/BLAST/.

\subsection{PCR quantification}

For relative quantification purposes $\log _{10}$ of fluorescence was plotted as a function of cycle number using iCycler iQ Optical System software Version 3.0a (Bio-Rad Laboratories). For each amplification curve, the point of maximal change was determined using the second derivative of fluorescence $(\mathrm{dd} F / \mathrm{d} t)$. Threshold was then set as the mean of maximal $\mathrm{dd} F / \mathrm{d} t$ 's for all amplification reactions processed together. Cycle threshold $\left(C_{\mathrm{t}}\right)$ was determined as the point at which an amplification curve crossed this threshold. Defined this way, $C_{\mathrm{t}}$ is inversely related to the relative level of expression of a particular gene (Bustin, 2004).

For each LCM cap, amplification of neuronal and glial markers was performed as well as amplifications of the reference genes. All reactions were performed in triplicate and $C_{\mathrm{t}} \mathrm{s}$ of all replicates for a given reaction were averaged. Those replicates that were $\geq 1 C_{\mathrm{t}}$ away from the mean were excluded, and the mean was recalculated from the two remaining replicates. We used Ppia, snRNP, and Gapd as reference genes; the reference $C_{\mathrm{t}}$ was calculated by averaging $C_{\mathrm{t}} \mathrm{s}$ of all three reference genes. Rel-

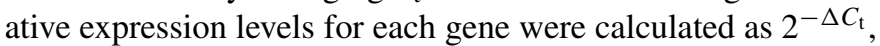
where $\Delta C_{\mathrm{t}}$ is the difference in $C_{\mathrm{t}}$ between the gene of interest and reference $C_{\mathrm{t}}$. For Plp and Mag differences in expression levels were calculated as $\left(2^{-\Delta C_{\mathrm{t}}}\right.$ white matter $) /\left(2^{-\Delta C_{\mathrm{t}}}\right.$ granular layer $)$, while for Eno2 and $\mathrm{Nfl}$ an inverse of the above relationship was used.

\subsection{Data analysis}

Statistical analyses were carried out with the Student's $t$-tests and regression analyses in Microsoft Excel 2003. Differences among multiple means were evaluated with one-way ANOVA and Scheffe post hoc testing using SPSS Version 13.0. $p$-Values from multiple $t$-tests were corrected with the Bonferroni correction. Significance level was set as $p<0.05$; data are presented as mean \pm standard error of the mean (S.E.M.).

\section{Results}

\subsection{RNA quality control-tissue scrapes}

Our initial experiments examined effect of various tissue handling manipulations, which may be necessary for preparing tissue for LCM, but may also potentially affect the quality of isolated RNA. Using a total of 118 tissue scrape preparations from five rats, we tested the effects of slide type, tissue sectioning approaches as well as effects of different tissue staining approaches. In these experiments tissue sections were mounted either onto positively charged or poly-lysine coated slides, and were collected either unstained or following staining with cresyl violet or neutral red and dehydration. To determine the impact that an increase in processing time and complexity of the preparation protocol may have on RNA integrity, tissue sections were collected from slides that had a different number of total sections mounted onto them. Accordingly, some slides contained only one tissue section, while others contained either two or four sections. Thus, we were able to obtain a range of times that sections remained at room temperature during sectioning.

Preliminary analysis suggested no difference in RNA quality between sections mounted on poly-lysine slides or onto charged slides, therefore, subsequent analyses ignored this variable. In contrast, cresyl violet or neutral red staining had significant negative effects on RNA integrity as determined with all three quality measures. In this analysis tissue scrapes were performed on sections obtained from the same animals and located on consecutive slides, thus ensuring that extracted RNA was from the same animal group. In such series adjacent slides were either stained or non-stained, thus allowing direct comparisons of the effects of staining. Unstained tissue sections ( $n=50)$ yielded $28 \mathrm{~s} / 18 \mathrm{~s}$ of $1.18 \pm 0.02$, RIN of $7.48 \pm 0.06$, and $18 \mathrm{~s} / \mathrm{b}$ aseline of $7.59 \pm 0.24$. In contrast, RNA isolated from cresyl violet-stained sections $(n=48)$ was of poorer quality and had the following profile: $28 \mathrm{~s} / 18 \mathrm{~s}$ ratio of $0.87 \pm 0.02$, RIN of $6.39 \pm 0.08$, and $18 \mathrm{~s} /$ baseline ratio of $5.10 \pm 0.17$, while in neutral red-stained tissue $(n=20)$ these parameters were as follows: $28 \mathrm{~s} / 18 \mathrm{~s}$ ratio of $0.87 \pm 0.02, \mathrm{RIN}$ of $6.37 \pm 0.08,18 \mathrm{~s} /$ baseline ratio of $4.83 \pm 0.17$. These data were analyzed with one-way ANOVA with each quality measure as a dependent variable and each staining paradigm as a factor. Differences were statistically significant $(p<0.05)$, and post hoc testing revealed equivalent decrease in RNA quality with the two staining approaches (cresyl violet and neutral red) as quantified with all three RNA quality measures. This decrease in RNA quality was significantly different than that from the non-stained tissue $(p<0.05$; Fig. 5A).

To determine the effects of different staining approaches on the concentration of recovered RNA, we quantified RNA concentration from tissue scrapes in each of the three conditions: non-stained tissue, tissue stained with neutral red, and tissue stained with cresyl violet. Fig. 6A illustrates differences in the concentration of recovered RNA, which were $24.6 \pm 1.2 \mathrm{ng} / \mu \mathrm{l}$ for non-stained tissue, $34.4 \pm 2.4 \mathrm{ng} / \mu \mathrm{l}$ for neutral red-stained tissue, and $23.8 \pm 1.4 \mathrm{ng} / \mu \mathrm{l}$ for cresyl violet-stained tissue. RNA concentration was significantly greater in the neutral red-stained tissue than in either cresyl violet-stained or the non-stained tissue (Fig. 6A).

To determine whether sectioning strategy during tissue preparation can influence RNA quality, we sectioned the tissue to contain either one, two, or four slides per section (see Section 2 for additional details). This approach yielded groups of sections that were exposed to ambient air during sectioning for an average of $0,90,110,180,220,330$, and 420 s. Since initial analysis indicated a statistically significant difference in RNA quality between stained and non-stained tissue, possible effects of exposure to room temperature on RNA quality were evalu- 

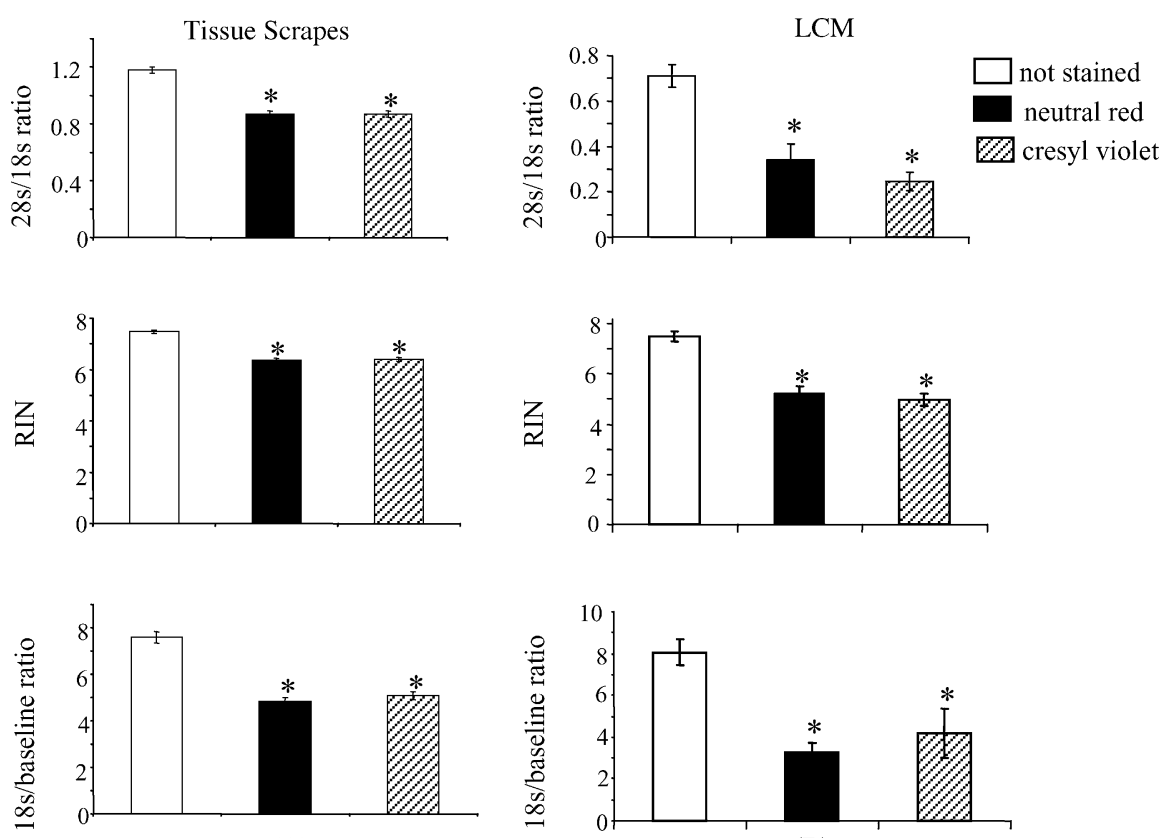

(A)

(B)

Fig. 5. Decrease in RNA integrity measures following tissue staining with neutral red or with cresyl violet. RNA integrity was assessed using three different measures: 28s/18s rRNA subunit ratio, 18s rRNA subunit peak height divided by the height of the tallest peak within the preceding baseline (18s/baseline ratio), and RNA integrity number (RIN). Data are shown as mean \pm standard error of the mean. ${ }^{*} p<0.05$ as compared to unstained samples.

Tissue Scrapes

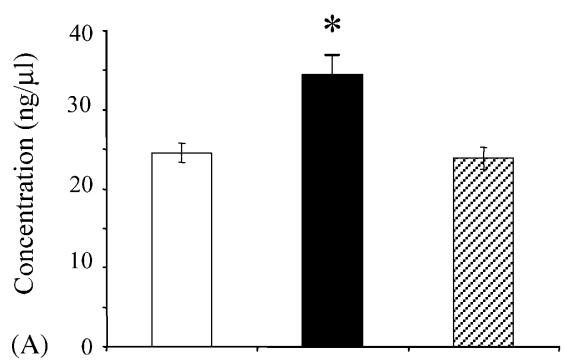

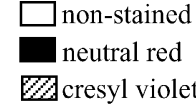

LCM

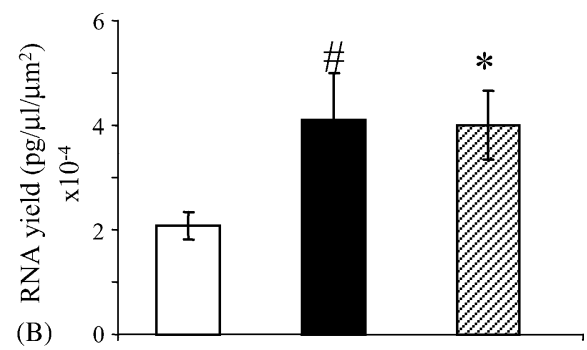

Fig. 6. Increases in RNA concentration and yield in stained tissue scrapes (A) and in microdissected samples (B). In microdissected samples yield was calculated by dividing RNA concentration (in $\mathrm{pg} / \mu \mathrm{l}$ ) by the area of the captured sample (in $\mu \mathrm{m}^{2}$ ). ${ }^{*} p<0.05$ compared to non-stained tissue, ${ }^{\#} p=0.06$ compared to non-stained tissue.

ated separately in stained and non-stained tissue scrapes. For the non-stained tissue, four to eight tissue scrapes per time point were analyzed. Preliminary analysis revealed no difference in quality for the samples collected after 0-220 s at room temperature. But there appeared to be a decrease in the $28 \mathrm{~s} / 18 \mathrm{~s}$ at the two subsequent points. For the purpose of statistical analysis, $28 \mathrm{~s} / 18 \mathrm{~s}$ values for samples exposed to room temperature from 0 to $220 \mathrm{~s}$ were pooled together into one group $(n=31)$, while samples exposed to room temperature for either $330 \mathrm{~s}(n=8)$, which corresponds to section \#2 of the four sections per slide, or $420 \mathrm{~s}(n=8)$, which corresponds to section \#1 of the four sections per slide, remained as separate groups. Analysis with one-way ANOVA revealed statistically significant differences in the distribution of the three means $(p<0.05)$, while Scheffe post hoc testing revealed a statistically significant difference between 0 and $220 \mathrm{~s}$ group and the $420 \mathrm{~s}$ group $(p<0.01 ;$ Fig. 7$)$. No significant effect of time at room temperature on RNA quality was observed with the other two measures of RNA quality. In the stained tissue group a total of 68 tissue scrapes were analyzed, $n=4-13$ per group. There was no correlation between time at room temperature and RNA quality for any of the measures in this group.

\subsection{RNA quality control $-L C M$}

In order to determine whether tissue scrapes analyses are accurate predictors of factors that influence RNA quality and recovery during laser capture microdissection, similar quality 


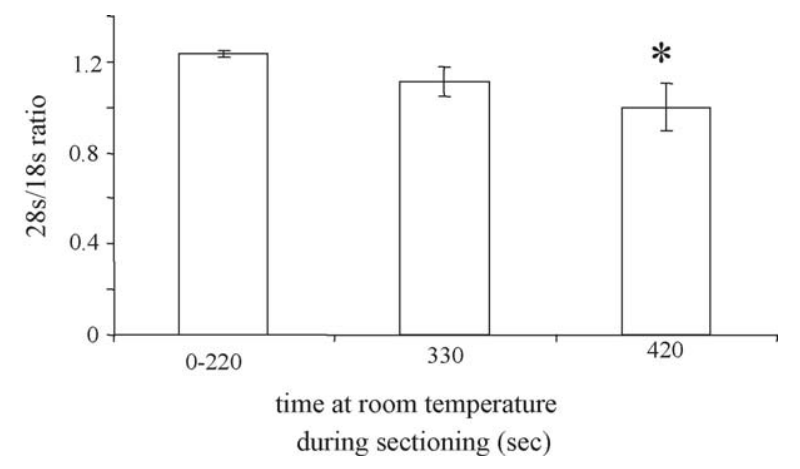

Fig. 7. Time at room temperature during sectioning negatively impacts the quality of extracted RNA as measured with $28 \mathrm{~s} / 18 \mathrm{~s}$ ratio. ${ }^{*} p<0.05$ compared to 0-220 s group.

and concentration analyses were performed on microdissected tissue. For this analysis a total of 58 microdissected samples were collected either from the cerebellar white matter or the granular layer (see below for microdissection details). These samples were collected from four rats with 11-17 microdissected samples per rat. Of these, 25 samples were obtained from non-stained tissue, 19 were collected from cresyl violet-stained tissue, and 14 were microdissected from neutral red-stained tissue. Effects of staining on RNA quality were similar to those observed in tissue scrapes, and were as follows: non-stained samples-28s $/ 18 \mathrm{~s}$ of $0.71 \pm 0.05$, RIN of $7.51 \pm 0.21,18 \mathrm{~s} /$ baseline of $8.07 \pm 0.61$; cresyl violet-stained samples-28s/18s of $0.25 \pm 0.04$, RIN of $4.98 \pm 0.24,18 \mathrm{~s} / \mathrm{baseline}$ of $4.20 \pm 1.16$; neutral redstained samples-28s $/ 18 \mathrm{~s}$ of $0.34 \pm 0.07$, RIN of $5.24 \pm 0.30$, $18 \mathrm{~s} /$ baseline of $3.30 \pm 0.40$. For all three measures, staining had a similar impact in microdissected samples as in tissue scrapes - tissue stained with either cresyl violet or neutral red had significantly decreased RNA quality as compared to the non-stained tissue (Fig. 5B).

To determine whether quantity of RNA extracted from microdissected tissue samples is affected by different staining strategies, we calculated RNA yield by dividing the concentration of extracted RNA in $(\mathrm{pg} / \mu \mathrm{l})$ by the size of the captured area (in $\mu \mathrm{m}^{2}$ ). The yield in the non-stained tissue was $2.1 \times 10^{-4} \pm 0.3 \times 10^{-5} \mathrm{pg} / \mu \mathrm{l} / \mu \mathrm{m}^{2}$, while in stained tissue there was a nearly two-fold increase in yield to $4.0 \times 10^{-4} \pm 0.6 \times 10^{-5} \mathrm{pg} / \mu \mathrm{l} / \mu \mathrm{m}^{2}$ for cresyl violet-stained tissue and $4.1 \times 10^{-4} \pm 0.9 \times 10^{-5} \mathrm{pg} / \mu \mathrm{l} / \mu \mathrm{m}^{2}$ for neutral redstained tissue. One-way ANOVA revealed significant differences among the means $(p<0.05)$, and post hoc testing revealed that RNA yield was significantly greater in cresyl violet-stained tissue $(p<0.05$; Fig. 6B). There was also a trend toward significance for the increase in yield in the neutral red-stained tissue $(p=0.06$; Fig. 6B).

To determine the possible effects of the LCM capture of various sizes on the RNA concentration and its detection capability by the Agilent BioAnalyzer, we correlated capture area (in $\mu \mathrm{m}^{2}$ ) with RNA concentration (in $\mathrm{pg} / \mu \mathrm{l}$ ) from tissue samples that had efficient microdissection captures as assessed by post-capture images. We examined the correlation between capture area and RNA concentration and found a weak $\left(r^{2}=0.12\right)$ but significant linear correlation $(p<0.05)$. These data suggest a direct relationship between RNA recovery and the size of the microdissected area. However, the weakness of this correlation, i.e. low $r^{2}$, is due to other factors that influence RNA recovery, such as tissue type (granular layer versus white matter layer), and stain preparation (stained versus non-stained). Nonetheless, we were able to determine that the minimum microdissected area that is likely to yield RNA within detectable range of the Agilent BioAnalyzer is about $1 \mathrm{~mm}^{2}$. We used this value as a guide for microdissecting IBO lesioned tissue in subsequent experiments

\subsection{Real-time PCR}

Real-time PCR experiments were designed to determine: (1) whether the present reverse transcription strategy and PCR primer design are compatible with gene expression studies employing small quantities of input RNA; (2) the limit of detection of the present qRT-PCR method; (3) the results of this approach using laser-capture microdissected tissues and compare it with known gene expression differences; (4) whether this technique can be used to detect gene expression differences in response to an experimental manipulation, such as a neurotoxic lesion.

To begin addressing these issues, qRT-PCRs using RNA from three different tissue scrapes were performed. These tissue scrapes produced a good yield of RNA, which was relatively intact. Each of the three samples was reverse transcribed separately and resultant cDNA was serially diluted. All dilutions were performed in duplicate and were prepared as follows: sample 1 cDNA (input total RNA concentration $592 \mathrm{pg} / \mu \mathrm{l}$ ) was diluted in eight serial steps, each at a 1:2 dilution. Sample 2 cDNA (input total RNA concentration $2644 \mathrm{pg} / \mu \mathrm{l}$ ) was diluted in eight serial steps, with the first seven at a 1:4 dilution and the last step at a 1:2 dilution. Sample 3 cDNA (input total RNA concentration $2814 \mathrm{pg} / \mu \mathrm{l}$ ) was diluted in six serial steps, each at a 1:4 dilution.

Real-time PCR for Mag, Plp, Ppia, and Eno2 was then carried out using these serial dilutions (Fig. 4). Thus, a total of 12 dilution series were amplified. Amplification efficiency was determined by plotting $C_{\mathrm{t}}$ as a function of dilution factor, expressed as $\log _{2}$. In theory, each PCR cycle should double the DNA concentration, thus producing a linear correlation with a slope of one. For each dilution, $C_{\mathrm{t}} \mathrm{s}$ of the two replicates were averaged and plotted as a function of the dilution factor, expressed as $\log _{2}$ (Fig. 4, inset). Regression analyses revealed a strong positive correlation between $C_{\mathrm{t}}$ and dilution factor $\left(r^{2}=0.95 \pm 0.01(n=12)\right)$, as well as a high amplification efficiency (slope $=1.04 \pm 0.01(n=12))$ for all of the dilution series.

To determine the lowest concentration of input RNA that may be compatible with our qRT-PCR strategy, we focused on the data from the most dilute samples. The data from these specimens are represented by the right-most points on the efficiency plots (Fig. 4, inset). We deemed these data points to be valid if they fell on the amplification efficiency regression line generated by higher concentration specimens (left-most points; Fig. 4). This approach indicated that the lowest concentrations of total 
RNA compatible with qRT-PCR were as follows: $1.9 \pm 0.6 \mathrm{pg} / \mu \mathrm{l}$ for $\operatorname{Eno} 2(n=3), 2.1 \pm 0.4 \mathrm{pg} / \mu \mathrm{l}$ for $\operatorname{Mag}(n=3), 1.1 \pm 0.6 \mathrm{pg} / \mu \mathrm{l}$ for Plp $(n=3)$, and $1.1 \pm 0.6 \mathrm{pg} / \mu \mathrm{l}$ for Ppia $(n=3)$.

To determine whether laser capture microdissected tissue may be used to produce valid qRT-PCR data, we used rat cerebellum as an experimental model. Cerebellar cortex consists of well-delineated and relatively homogeneous layers, including the granular layer, made up predominantly of neuronal cell bodies, and the white matter layer, containing mostly glia and axons (Fig. 1). In these experiments we microdissected cerebellar white matter or cerebellar granular layer onto individual LCM caps. In each case a single cap contained a single microdissected area. To accurately determine the laminar organization of the cerebellum, some of the tissue used in these studies was stained with either cresyl violet or neutral red (Fig. 1B). We were also able to differentiate between the granular cell layer and the white matter layer in unstained tissue sections (Fig. 1C). In such cases granular layer was readily identified based on its characteristic cellular density and its close proximity to the white matter layer, which was readily identified by its dark and uniform appearance (Fig. 1C). A total of 55 microdissected samples were collected for this analysis. Of these 25 were from the granular layer and 30 were from the white matter layer. Of the granular layer samples 12 were collected from cresyl violet-stained sections, 4 from neutral red-stained sections, and 9 from nonstained sections. For the samples collected from the white matter layer, 7 were collected from cresyl violet-stained sections, 8 were from neutral red-stained sections, and 15 were collected from non-stained tissue. Tissue sections used for this analysis remained at room temperature for either 110 or $420 \mathrm{~s}$ during sectioning.

For quantification of gene expression differences within cerebellar layers, we performed a total of 1278 replicates for 426 gene expression assays. The replicates were averaged and those that were $\geq 1 C_{\mathrm{t}}$ away from the mean were excluded and the mean was recalculated; a total of 38 replicates (3\% of the total) met exclusion criteria. As a measure of internal consistency, we calculated the coefficient of variance for each set of triplicates, which was $1.48 \%$ for all reactions.

Mean $\Delta C_{\mathrm{t}}$ s for the granular layer $(n=25)$ were as follows: Plp 4.09 \pm 0.30 , Mag $-5.17 \pm 0.15$, Nfl $5.37 \pm 0.21$, and Eno2 $-0.83 \pm 0.07$. For the white matter layer mean $\Delta C_{\mathrm{t}} \mathrm{s}(n=30)$ were: Plp $-2.64 \pm 0.26$, Mag $-0.43 \pm 0.15$, Nfl $4.10 \pm 0.21$, and Eno2 $1.64 \pm 0.18$ (see Fig. 8 for an example). Fold differences in expression of these genes between the two cerebellar layers were performed by comparing 25 of the samples microdissected from the granular layer with an equal number of samples collected from the white matter, which were randomly selected from a total of 30 samples. This analysis revealed significant increases in the expression of Mag and Plp in the white matter layer as compared to the granular layer $-73.7 \pm 11.5$ fold $(p<0.01)$ and $159.4 \pm 40.2$-fold $(p<0.01)$, respectively. Likewise, expression of $\mathrm{Nfl}$ was significantly greater within the white matter layer at $5.0 \pm 1.5$-fold $(p<0.05)$. In contrast, expression of Eno2 was $7.3 \pm 0.9$-fold greater $(p<0.01)$ in the granular layer as compared to the white matter layer (Fig. 9).
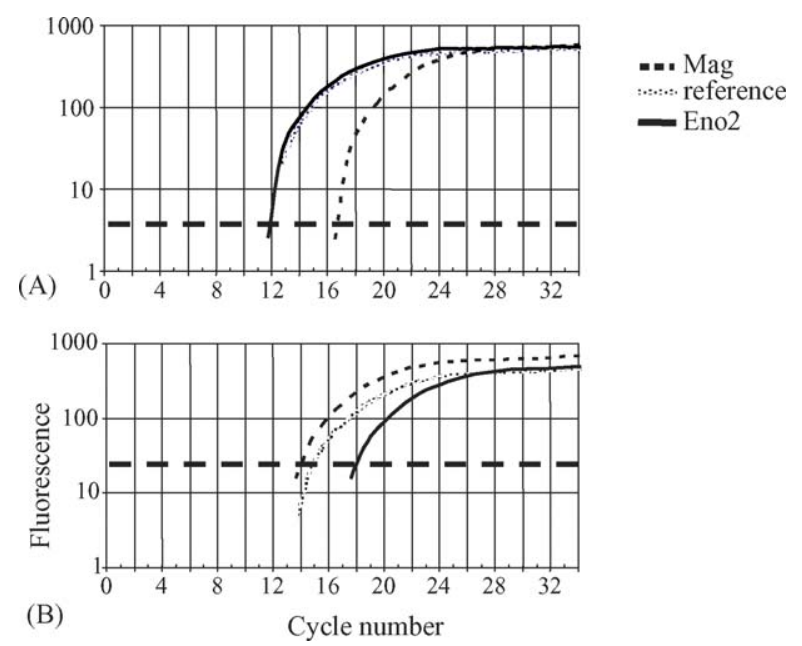

Fig. 8. Differential levels of expression of myelin-associated glycoprotein (Mag) and neuron-specific enolase (Eno2) in the cerebellar white matter and the granular layer. Reference amplification curve was derived by averaging amplifications of Gapd, Ppia, and snRNP. Amplification curves for Mag and Eno2 represent averages of three replicates. Threshold is indicated by the horizontal dashed line. $\Delta C_{\mathrm{t}}$ was calculated as $C_{\mathrm{t}}$ gene $-C_{\mathrm{t}}$ reference. Note the increase in Mag $\Delta C_{\mathrm{t}}$, the difference between Mag $C_{\mathrm{t}}$ and reference $C_{\mathrm{t}}$ in the granular layer (A) as compared to the white matter layer (B). The opposite is true for Eno2. In this example, there is about a 8-fold increase in the expression of Eno2 in the granular layer as compared to the white matter layer, and approximately a 64fold increase in Mag expression in the white matter as compared to the granular layer.

\subsection{Effects of RNA quality on $q R T-P C R$}

To determine whether RNA quality has an impact on the outcome of qRT-PCR studies, and to ascertain the sensitivity of each RNA quality measure at predicting the outcome of qRTPCR studies, we first correlated the three RNA quality measures to each other, using data collected from tissue scrapes and from

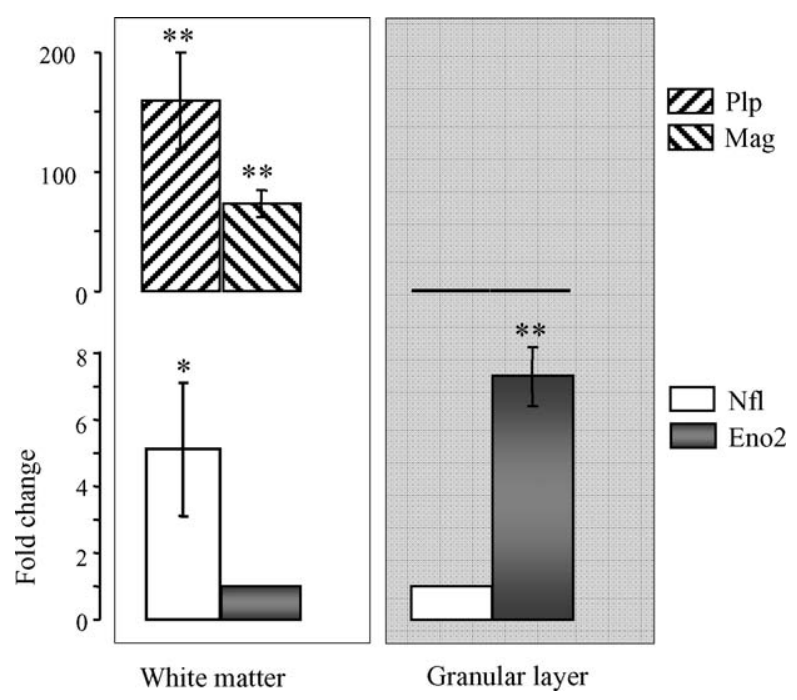

Fig. 9. Differences in gene expression levels between the cerebellar white matter and the granular layer. Relative expression differences are shown as mean fold changes \pm S.E.M. For Mag, Plp, and Nfl gene expression changes were standardized to the expression levels in the granular layer. In contrast, differences in Eno2 expression were standardized to the expression levels in the white matter. 

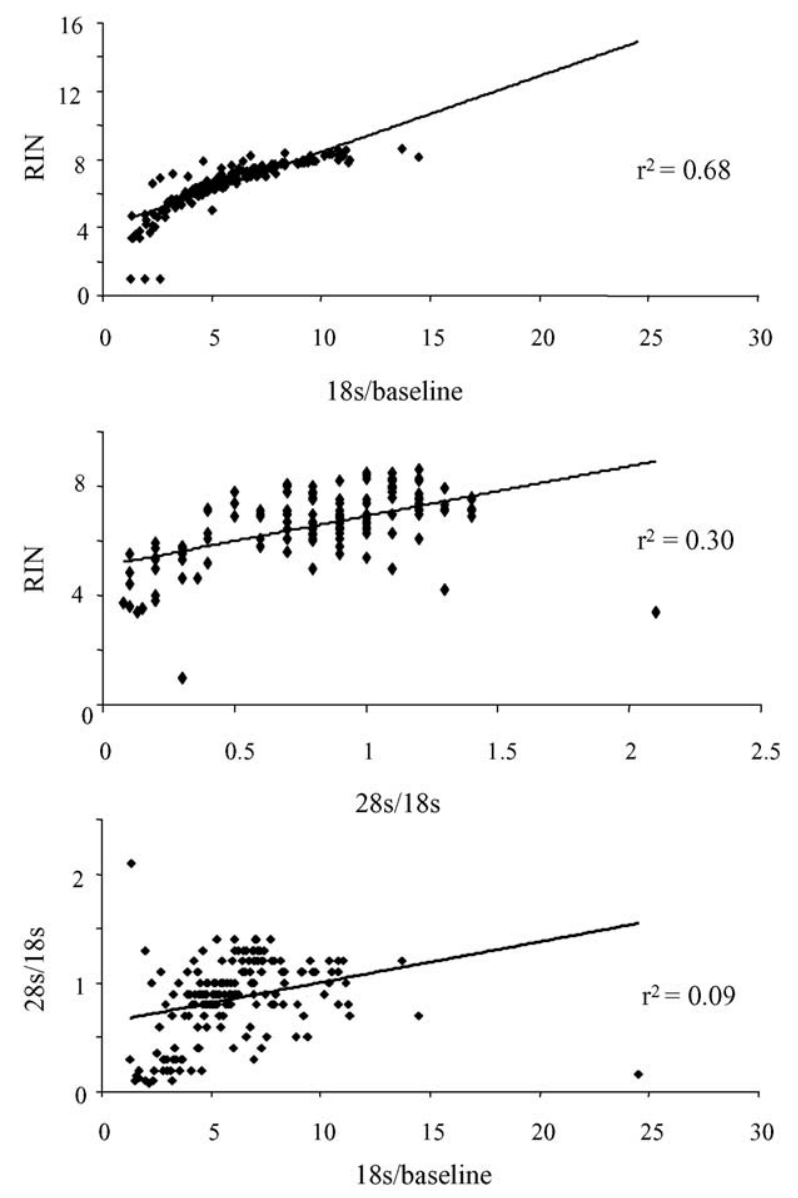

Fig. 10. Correlation of different RNA quality measures to each other. Top: RIN to 18s/baseline, middle: RIN to $28 \mathrm{~s} / 18 \mathrm{~s}$, bottom: $28 \mathrm{~s} / 18 \mathrm{~s}$ to $18 \mathrm{~s} /$ baseline. Samples from tissue scrapes and LCM were used for each analysis.

microdissected samples. These analyses revealed that RIN had a relatively strong correlation with $18 \mathrm{~s} /$ baseline $\left(r^{2}=0.68\right)$, while the correlation between $28 \mathrm{~s} / 18 \mathrm{~s}$ and $18 \mathrm{~s} /$ baseline was much weaker $\left(r^{2}=0.09\right)$; correlation between RIN and $28 \mathrm{~s} / 18 \mathrm{~s}$ was at an intermediate level $\left(r^{2}=0.30\right)$ (Fig. 10).

We then sorted microdissected samples based on their quality profile. We performed this procedure separately for each of the quality measures and selected the top six samples with high quality RNA and the bottom six samples with low quality RNA. Since the RNA quality measures did not correlate perfectly, the samples that were compared in each of these analyses were not always the same. We then compared Eno2, Mag, Nfl, and Plp $\Delta C_{\mathrm{t}} \mathrm{s}$ between microdissected samples with high quality RNA and those with low quality RNA within the following groups: granular layer high quality RNA group, granular layer low quality RNA group, white matter high quality RNA group, white matter low quality RNA group. RNA quality parameters for the samples were as follows: $28 \mathrm{~s} / 18 \mathrm{~s}$ ratio: low quality granular layer $-0.14 \pm 0.02$, high quality granular layer $-1.00 \pm 0.04$, low quality white matter $-0.14 \pm 0.02$, high quality white matter $-0.85 \pm 0.03$; RIN: low quality granular layer-3.6 \pm 0.1 , high quality granular layer- $8.1 \pm 0.2$, low quality white matter $-4.7 \pm 0.2$, high quality white matter $-8.0 \pm 0.1 ; 18 \mathrm{~s} /$ baseline peak ratio: low quality granular layer- $1.8 \pm 0.1$, high quality granular layer-9.3 \pm 0.6 , low quality white matter-2.3 \pm 0.3 , high quality white matter-13.8 \pm 1.9 . These differences in quality allowed direct examination of the effects of quality on $\Delta C_{\mathrm{t}}$ for each gene within each cerebellar layer. Separation of microdissected samples based on their RIN produced the most robust differences as it produced significant differences in the expression of 3 genes within the granular layer-Eno2, Nfl, and Plp, and in the expression Plp in the white matter (Fig. 11A). On the other hand, separation of samples based on the other two RNA quality measures had lower sensitivity as they did not predict all of the $\Delta C_{\mathrm{t}}$ differences. Accordingly, when the samples were sorted by their $18 \mathrm{~s} /$ baseline ratio only expression of Plp and $\mathrm{Nfl}$ in the granular layer was significantly different between highand low-quality RNA samples. No differences were observed in the white matter samples. Likewise, separation of samples based on their $28 \mathrm{~s} / 18 \mathrm{~s}$ ratio produced significant differences in the expression of Plp in the granular layer and the white matter and that of $\mathrm{Nfl}$ in the granular layer.

\subsection{Effects of RNA yield on $q R T-P C R$}

To ascertain whether RNA yield has an impact on the outcome of qRT-PCR experiments, we sorted microdissected samples by their yield. We then compared $\Delta C_{\mathrm{t}} \mathrm{s}$ for Eno2, Mag, Plp, and $\mathrm{Nfl}$ the top six samples with the bottom six samples in the granular layer and in the white matter layer. Low-yield samples contained $271 \pm 42 \mathrm{pg} / \mu \mathrm{l}$ for the granular layer and $142 \pm 11 \mathrm{pg} / \mu \mathrm{l}$ for the white matter; high-yield matter samples contained $2519 \pm 521 \mathrm{pg} / \mu \mathrm{l}$ for the granular layer and $1216 \pm 329 \mathrm{pg} / \mu \mathrm{l}$ for the white matter. This analysis revealed significant differences in the expression of Mag in the granular layer and that of $\mathrm{Nfl}$ in the white matter layer (Fig. 11B).

\subsection{Ibotenic acid lesions}

To further assess the sensitivity of combining LCM with qRTPCR, we made neurotoxic lesions within the cerebellar cortex of three rats using IBO injections. Following these injections, animals developed an ipsilateral gait impairment, and at a $24 \mathrm{~h}$ survival period a moderate loss of granular cells in the cerebellar cortex was evident on the injected side (Fig. 12). To determine gene expression differences in response to IBO, we microdissected four to five granular layer samples from each rat (total $n=14$ ); these captures were from tissue that was stained with cresyl violet to facilitate identification of the lesion. Eno2 $\Delta C_{\mathrm{t}} \mathrm{s}$ from the lesioned samples were compared to those from granular layer samples $(n=15)$, which were collected from intact rats from tissue that was stained with either with cresyl violet or neutral red. Eno2 $\Delta C_{\mathrm{t}} \mathrm{s}$ were significantly higher in the lesioned samples as compared to the non-lesioned ones $(p<0.01)$ and were $-0.1 \pm 0.1$ and $-0.8 \pm 0.1$, respectively (Fig. 12). The resultant $\Delta \Delta C_{\mathrm{t}}$ difference corresponds to a $38 \%$ decrease in the expression of granular layer Eno2 following IBO administration. This change was specific for Eno2 as there were no differences for Mag or Plp $\Delta C_{\mathrm{t}}$ s between lesioned and non-lesioned animals (Fig. 12). 

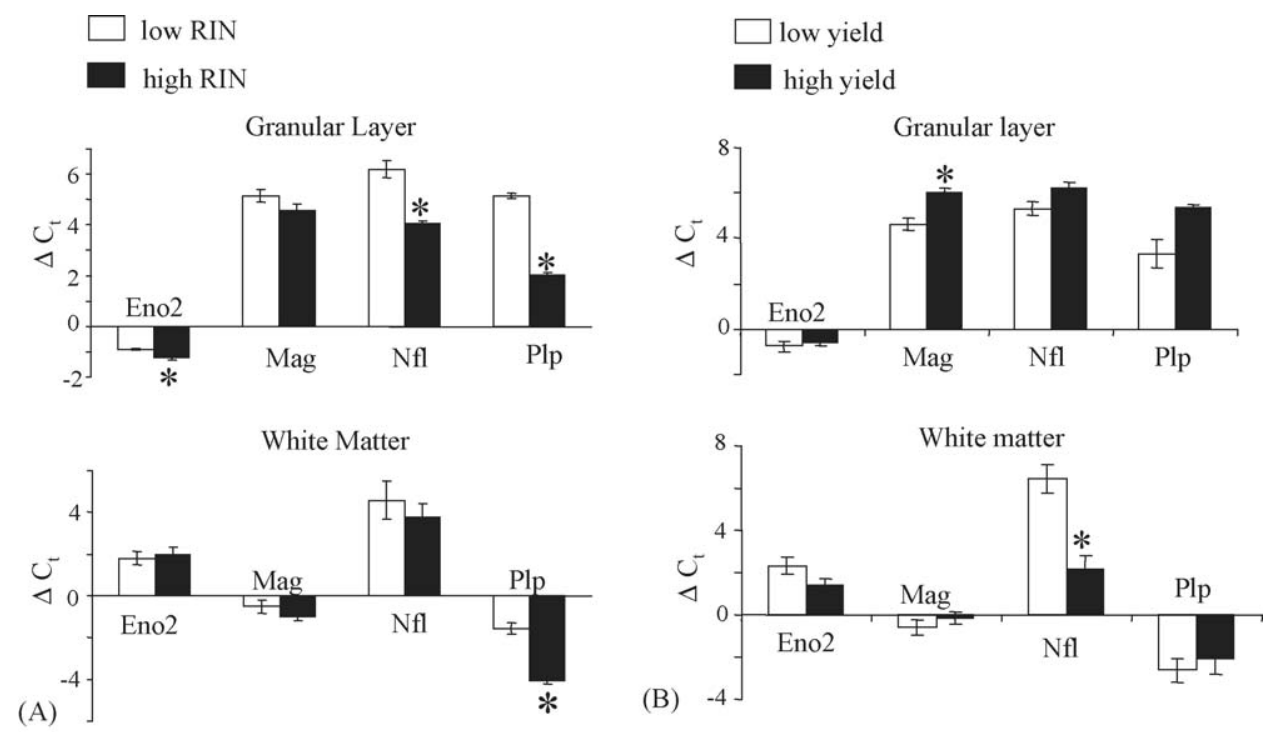

Fig. 11. Effect of RNA quality (A) and RNA yield (B) on gene expression. Microdissected samples were sorted based on the quality of their RNA, and $\Delta C_{t} s$ of the low-quality group were compared to those of the high quality group (A). Tissue samples were then re-sorted based on their RNA yield and $\Delta C_{\mathrm{t}} \mathrm{s}$ of the low-yield group were compared to those of the high-yield group (B). ${ }^{*} p<0.05$ compared to low RIN group (A) or to low yield group (B), Student's $t$-test with the Bonferroni correction.

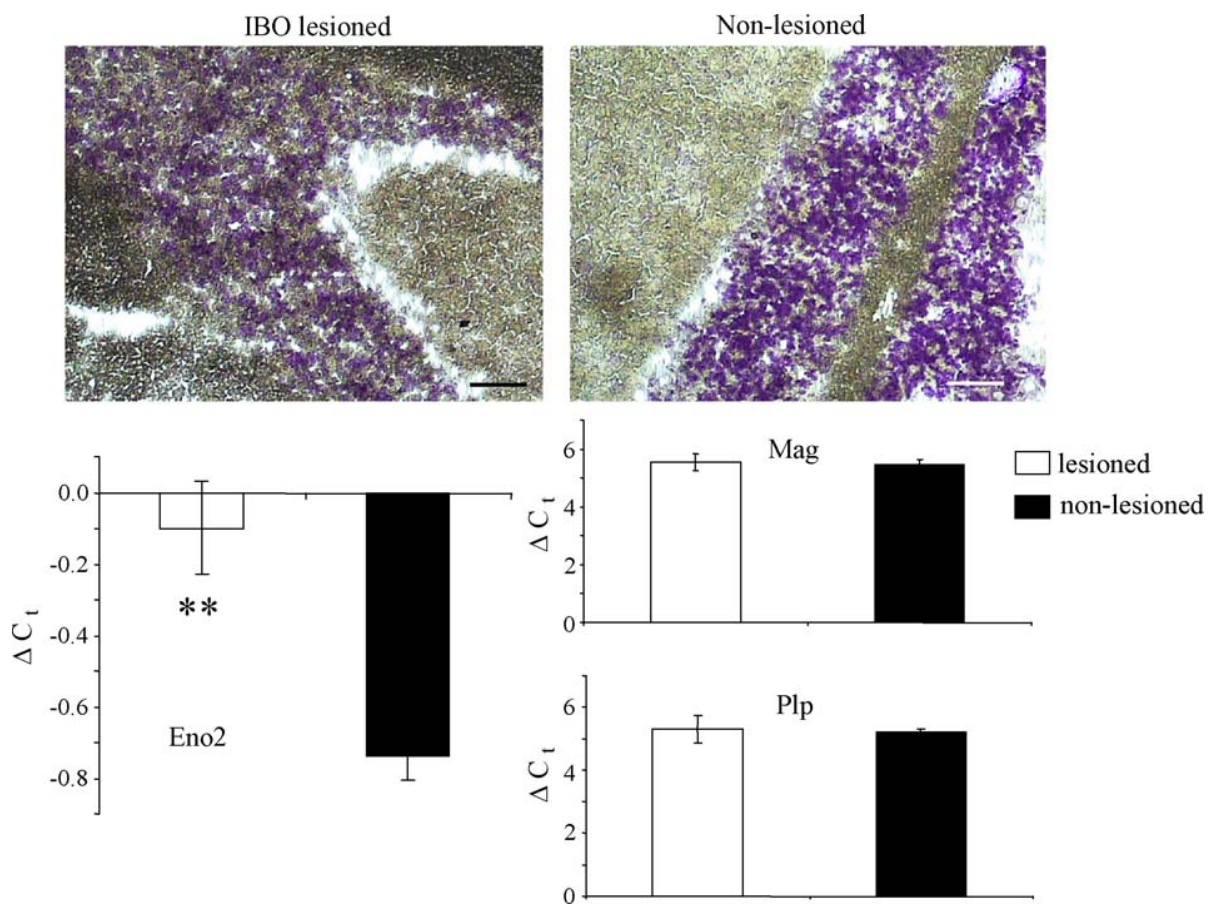

Fig. 12. Effects of a neurotoxic lesion on gene expression levels within the granular layer. Ibotenic acid (TBO) injection into the cerebellum led to a modest decrease in cell density and overall staining intensity in the cerebellar granular layer on the injected side (top left) as compared to the contralateral side (top right) of the cerebellar cortex. This led to a selective decrease in the Eno2 $\Delta C_{\mathrm{t}}$ (bottom left) but not of that for Mag (middle right) or Plp (bottom right). ${ }^{* *} p<0.01$ compared to non-lesioned samples.

\section{Discussion}

LCM is increasingly being used to harvest tissue for downstream gene expression analyses. The present study focused on different experimental manipulations that may contribute to RNA degradation during tissue preparation for LCM. We also described a qRT-PCR strategy that is compatible with gene expression analyses in samples with small amounts of starting
RNA. This approach was validated by microdissecting specific subregions of the rat cerebellum both in the normal tissue and following ibotenic acid injections.

\subsection{RNA quality control}

A classic measure of RNA integrity is the 28s/18s rRNA subunit ratio, which has been developed for gel-based RNA char- 
acterization approaches (Margan et al., 2000). However, recent reports have recommended alternative RNA characterization methods in studies using small amounts of total RNA. Accordingly, it has been suggested that most of the mRNA species are comparable in size to the 18s rRNA subunit (Miller et al., 2004). Increased mRNA degradation, therefore, would be characterized by a decrease in the $18 \mathrm{~s}$ peak and an increase in the height of preceding peaks. Hence, a recent study has suggested that the use of 18s rRNA peak height ratio to the highest peak in the baseline preceding the $18 \mathrm{~s}$ to be a more meaningful measure of RNA quality than the 28s/18s ratio (Miller et al., 2004). Likewise, another report has suggested that an automated analysis of the whole electropherogram, not just the $18 \mathrm{~s}$ and $28 \mathrm{~s}$ peaks, may yield more meaningful and reproducible data (Mueller et al., 2004). Such analysis has been incorporated into the latest beta-version of the Agilent Bio Analyzer software; this feature generates a quantifiable parameter-the RNA integrity number (RIN), which ranges from 10 (intact RNA) to 1 (degraded RNA) (Mueller et al., 2004). In our study we used all three of these parameters to measure RNA integrity. Our data demonstrate that though they all change in the same direction with each manipulation, they do not correlate to the same degree. RIN correlated strongly with $18 \mathrm{~s} /$ baseline and fairly well with $28 \mathrm{~s} / 18 \mathrm{~s}$, while the correlation between $28 \mathrm{~s} / 18 \mathrm{~s}$ and $18 \mathrm{~s} /$ baseline was very weak. These findings suggest that 28s/18s and 18s/baseline measure very different variables, but since RIN correlates with both of them it can reflect changes in both of these parameters. Furthermore, RNA integrities predicted by RIN were better supported by qRT-PCR data. Taken together these data suggest that RIN is the measure of choice when evaluating RNA integrity from LCM sample for qRT-PCR studies. Our data also indicate that it is possible to effectively determine the impact of various staining strategies on RNA quality in microdissected samples by using tissue scrapes as a model system. Thus, using tissue scrape preparations to first maximize the quality of extracted RNA before proceeding on to LCM may be a more effective and cost efficient strategy in studies employing novel staining paradigms.

In addition to RNA quality we found that RNA yield is also an important determinant of gene expression levels. Our data indicate that expression of Mag is sensitive to RNA yield but not quality, while that of $\mathrm{Nfl}$ is influenced by both. Conversely, expression of Plp is very sensitive to quality but not yield. These data indicate the importance of maximizing RNA integrity in qRT-PCR studies since RNA degradation and decrease yield had a significant impact on $\Delta C_{\mathrm{t}} \mathrm{s}$ of multiple genes. Interestingly, some of the genes were sensitive to both changes in yield and quality, while others were influenced by only one of these variables. This finding is consistent with other reports that have found a major impact of RNA quality on gene expression profiles, which are likely due to variability in stability among different mRNA species (Bustin and Nolan, 2004; Hargrove and Schmidt, 1989; Li et al., 2004; Pardue et al., 1994; Tomita et al., 2004). This issue would also be crucial to keep in mind for experiments where there may be some deviation in sample preparation, for example in samples taken from post-mortem human brain.
Interestingly, we found that in LCM experiments RNA yield can be increased by staining the tissue with either cresyl violet or neutral red. Staining with neutral red increased RNA concentration in tissue scrapes and showed a similar trend $(p=0.06)$ in microdissected samples. The effect in microdissected samples did not reach significance, it seems likely, however, that this difference would have been significant with increased replication. Additionally, cresyl violet-stainning significantly increased RNA yield in microdissected samples. Taken together these data suggest that there may be something intrinsic to some Nissl stains that maximizes RNA yield, and that this effect on yield is increased with microdissection. This effect is probably due to increased binding of stained tissue to the plastic on the LCM cap, and in fact we have found that staining sections leads to improved tissue pick up during the microdissection process (unpublished observations).

As mentioned previously there are multiple LCM platforms currently available. These instruments are all slightly different from each other, each requiring specific protocols. In this study we focused on the different parameters in the tissue preparation protocol for the AutoPix. This machine requires that the sections are thinly cut, $\leq 10 \mu \mathrm{m}$, are mounted on glass slides and dehydrated prior to microdissection. For anatomical resolution sections may need to be stained, using either a Nissl stain or an immunofluorescent approach. Our data indicate that RNA integrity is strongly influenced by the complexity of the tissue preparation protocol. Quality of total RNA begins to diminish as the sectioning strategy is altered to increase the number of sections per slide. The difference in RNA integrity between tissue sections that were mounted one per slide as compared to those mounted as two per slide appeared minimal. However, when the number of sections was increased to four per slide, RNA quality dropped considerably. This effect is most likely due to the unchecked RNase activity taking place at room temperature. Since during tissue sectioning the slides with multiple sections were kept at room temperature prior to mounting each section, it is likely that most of the RNA degradation took place at that time. It would be difficult to prevent this negative effect on RNA integrity, since each slide needs to be at room temperature prior to section mounting for effective tissue adhesion. Our data suggest that an effective way to avoid RNA degradation is to minimize the time that each section is left at room temperature during sectioning, and that RNA degradation begins to take effect after about $420 \mathrm{~s}$ at room temperature. Thus, for some applications requiring highest possible RNA quality, such as for quantification of expression of low-abundance genes, one or two sections per slide sectioning strategy may need to be used. On the other hand, other studies may be performed with partially degraded RNA and may, therefore, be carried out with four sections mounted on each slide.

A major application of LCM is to increase the homogeneity of tissue specimens from heterogeneous structures, such as the brain. For this purpose it is often required to stain the tissue. In our experiments we used two Nissl stains - cresyl violet or neutral red - for improved visualization. This resulted in a considerable $\sim 25 \%$ decrease in RNA integrity. This level of degradation was equivalent between cresyl violet- and neutral 
red-stained tissue, suggesting that this was not a stain-specific phenomenon. It may have been avoided by decreasing the duration of tissue exposure to the aqueous environment of the staining solution, since RNase activity is higher under such circumstances. However, in some cases this change may negatively impact the quality of histological detection. This was not the case in our study as we were able to confidently identify different cerebellar layers in unstained sections. These data highlight the need for the development of more effective RNase inhibition strategies for use in studies combining LCM with gene expression analyses, perhaps in collaboration with an industry partner.

\section{2. $q R T-P C R$}

In the current study, we used a 3'-biased method for reverse transcription and subsequent PCR. During reverse transcription, first strand cDNA synthesis was initiated with oligo(dT) primers. This strategy was chosen, instead of random hexamer primed reverse transcription, to ensure that most of the primers bound to mRNA rather than the more abundant rRNA, thus maximizing the yield of cDNA synthesis. Since activity of reverse transcriptase declines after several hundred or thousand bases, this led to the production of cDNA that was most intact at its $3^{\prime}$ end. To take advantage of this feature and to maximize the sensitivity of qRT-PCR, we used primers that amplified DNA segments closest to their $3^{\prime}$ end. We also used primers that spanned an intron, specifically the $3^{\prime}$-most intron of each transcript, thus enabling detection of genomic contaminants by their larger size. However, this approach may not always be feasible as for some transcripts it may not be possible to design PCR primers that are $3^{\prime}$-biased, span and intron, and yield amplicons without considerable secondary structure. To minimize contamination with genomic DNA, we treated RNA with DNase during the isolation process. Use of intron-spanning primers allowed us to detect genomic contaminants directly. Accordingly, we did not detect genomic contaminants in any of our amplifications, indicating high efficiency of the DNase treatment.

This approach proved very sensitive as our dilution experiments demonstrated. Accordingly, our data suggest that this qRT-PCR design can be used to quantify relative expression of transcripts in as little as $1.6 \mathrm{pg} / \mu \mathrm{l}$ of total RNA. Importantly, these calculations were made under the assumption of $100 \%$ efficiency of reverse transcription. In reality, however, the efficiency of this reaction is considerably lower. Nonetheless, these data suggest the possibility of quantifying gene expression in a single neuron using this strategy, since a single cell contains anywhere from 2 to $100 \mathrm{pg}$ of total RNA (Bustin, 2004; Sambrook and Russell, 2001).

This qRT-PCR strategy was also validated in the rat cerebellum, which has a clear laminar organization and includes layers that are enriched in neurons or glia. We observed large differences in the expression of glial and neuronal markers between the white matter layer and the granular layer of the cerebellum. Thus, expression of glial markers, Mag and Plp, was 70-160fold greater in the white matter layer. In contrast, expression of Eno2 was seven times higher in the granular layer than the white matter layer. These differences are consistent with previ- ous literature, which suggests that Mag and Plp are expressed exclusively in glia (Hartman et al., 1982; Salzer et al., 1987; Schachner and Bartsch, 2000; Stoffel et al., 1984), while Eno2 is expressed only in neurons (Schmechel et al., 1978a,b). Our findings of valid $C_{\mathrm{t}} \mathrm{s}$ for Mag and Plp in the granular layer and for Eno2 in the white matter layer suggest that these layers are not entirely homogeneous. Thus, although the granular layer is predominantly made up of neurons, it undoubtedly also contains glia as supporting elements. Likewise, the white matter layer may also contain some displaced neurons. Another possibility, however, is that there may be transport of Eno2 mRNA to axons, a phenomenon documented for other mRNA species (Piper and Holt, 2004).

In addition to the gene expression differences described above, we detected expression of Nfl both in the cerebellar white matter layer as well as the granular layer. This observation is consistent with other studies, which suggest that this transcript is expressed in neurons, glia, and Schwann cells (Luo et al., 1999; Sotelo-Silveira et al., 2000). Overall we found that it is expressed at a greater level in the white matter layer as compared to the granular layer. However, expression of this gene is particularly sensitive to RNA quality and yield. Consequently, if only low yield samples were analyzed, there likely would have been no difference in expression between the two cerebellar layers as $\Delta C_{\mathrm{t}}$ was about 6 in both (see Fig. 11). Likewise, expression levels of Mag were significantly affected by yield, and those of Eno2 and Plp were affected by quality. These findings highlight the importance of acquiring samples of highest possible RNA integrity.

In addition to characterizing large differences in gene expression in normal cerebellar tissue, we also demonstrated that this method may be used to detect relatively small changes in response to an experimental manipulation such IBO microinjection into the cerebellum. Different cell populations exhibit differential sensitivities to application of neurotoxins (Hastings et al., 1985; Inglis and Semba, 1997; Robbins et al., 1989). Our results indicate that cerebellar granular cells are relatively resistant to IBO, as there was only a modest decrease in their numbers in response to this treatment. Nonetheless were able to detect this change by qRT-PCR as expression of Eno2 decreased by $38 \%$ in the granular layer. It is important to note that this change was specific, as expression of Mag and Plp did not change, and thus cannot be attributed to non-specific effects of the injection.

\section{Conclusions}

Our study documents the effects of various experimental manipulations during tissue preparation for LCM. Using three different parameters for quantification of RNA integrity, we demonstrated that RNA quality decreases with increased complexity of the tissue preparation protocol. We also directly compared the sensitivity and predictive value of different RNA quality measurement approaches to qRT-PCR experiments and determined that RIN may be the measure of choice when such studies are performed on microdissected tissue. Our data suggest that manipulations that decrease the amount of time that the tissue is exposed to an aqueous environment at room temperature 
may decrease RNA degradation. However, even with partially degraded input RNA, 3'-biased qRT-PCR design may be used to reliably detect and quantify differences in expression of high abundance genes from small amounts of starting RNA. Differences in RNA integrity may also affect quantification of gene expression differences. This approach was validated in the rat cerebellum, in which qRT-PCR on LCM harvested tissue was used to quantify relative differences in the expression of neuronal and glial markers in the cerebellar white matter and the granular layer. In addition to quantifying these large differences in gene expression, our neurotoxic lesion studies demonstrated the utility of this method in the detection of relatively small changes (on the order of $40 \%$ or less).

This study demonstrates that the quality of isolated RNA is influenced by specific manipulations during tissue preparation for LCM. It also indicates that qRT-PCR can be successfully carried out with partially degraded input RNA, at least for high abundance transcripts. Future efforts will focus on improving the quality of extracted total RNA to facilitate the study of low abundance transcripts.

\section{Acknowledgements}

The authors would like to thank Dr. Monica Beneyto for her comments on an earlier version of the manuscript and Dr. Robert Thompson for his advice during the course of these studies. We are also grateful to Dr. Marco Cecchi for his help with ibotenic acid injections. This work was supported by Pritzker Neuropsychiatric Disorders Research Consortium and NIH grant P01 MH042251 awarded to S.J.W.

\section{References}

Aoyagi K, Tatsuta T, Nishigaki M, Akimoto S, Tanabe C, Omoto Y, et al. A faithful method for PCR-mediated global mRNA amplification and its integration into microarray analysis on laser-captured cells. Biochem Biophys Res Commun 2003;300:915-20.

Burbach GJ, Dehn D, Del Turco D, Deller T. Quantification of layer-specific gene expression in the hippocampus: effective use of laser microdissection in combination with quantitative RT-PCR. J Neurosci Methods 2003;131:83-91.

Burbach GJ, Dehn D, Nagel B, Del Turco D, Deller T. Laser microdissection of immunolabeled astrocytes allows quantification of astrocytic gene expression. J Neurosci Methods 2004;138:141-8.

Bustin SA. Tsigelny I, editor. A-Z of quantitative PCR. La Jolla, CA: International University Line; 2004, 882 p.

Bustin SA, Nolan T. Pitfalls of quantitative real-time reverse-transcription polymerase chain reaction. J Biomol Technol 2004;15:155-66.

Emmert-Buck MR, Bonner RF, Smith PD, Chuaqui RF, Zhuang Z, Goldstein SR, et al. Laser capture microdissection. Science 1996;274:998-1001.

Haque R, Chaurasia SS, Wessel 3rd JH, Iuvone PM. Dual regulation of cryptochrome $1 \mathrm{mRNA}$ expression in chicken retina by light and circadian oscillators. Neuroreport 2002;13:2247-51.

Hargrove JL, Schmidt FH. The role of mRNA and protein stability in gene expression. Faseb J 1989;3:2360-70.

Hartman BK, Agrawal HC, Agrawal D, Kalmbach S. Development and maturation of central nervous system myelin: comparison of immunohistochemical localization of proteolipid protein and basic protein in myelin and oligodendrocytes. Proc Natl Acad Sci USA 1982;79:4217-20.

Hastings MH, Winn P, Dunnett SB. Neurotoxic amino acid lesions of the lateral hypothalamus: a parametric comparison of the effects of ibotenate, $N$-methyl-D,L-aspartate and quisqualate in the rat. Brain Res 1985;360:248-56.

Heath PR, Tomkins J, Ince PG, Shaw PJ. Quantitative assessment of AMPA receptor mRNA in human spinal motor neurons isolated by laser capture microdissection. Neuroreport 2002;13:1753-7.

Inglis WL, Semba K. Discriminable excitotoxic effects of ibotenic acid, AMPA, NMDA and quinolinic acid in the rat laterodorsal tegmental nucleus. Brain Res 1997;755:17-27.

Jin L, Thompson CA, Qian X, Kuecker SJ, Kulig E, Lloyd RV. Analysis of anterior pituitary hormone mRNA expression in immunophenotypically characterized single cells after laser capture microdissection. Lab Invest 1999;79:511-2.

Kamme F, Salunga R, Yu J, Tran DT, Zhu J, Luo L, et al. Single-cell microarray analysis in hippocampus CA1: demonstration and validation of cellular heterogeneity. J Neurosci 2003;23:3607-15.

Li JZ, Vawter MP, Walsh DM, Tomita H, Evans SJ, Choudary PV, et al. Systematic changes in gene expression in postmortem human brains associated with tissue $\mathrm{pH}$ and terminal medical conditions. Hum Mol Genet 2004;13:609-16.

Lu L, Neff F, Dun Z, Hemmer B, Oertel WH, Schlegel J, et al. Gene expression profiles derived from single cells in human postmortem brain. Brain Res Brain Res Protoc 2004;13:18-25.

Luo L, Salunga RC, Guo H, Bittner A, Joy KC, Galindo JE, et al. Gene expression profiles of laser-captured adjacent neuronal subtypes. Nat Med 1999;5:117-22.

Luzzi V, Mahadevappa M, Raja R, Warrington JA, Watson MA. Accurate and reproducible gene expression profiles from laser capture microdissection, transcript amplification, and high density oligonucleotide microarray analysis. J Mol Diagn 2003;5:9-14.

Margan SH, Handelsman DJ, Mann S, Russell P, Rogers J, Khadra MH, et al. Quality of nucleic acids extracted from fresh prostatic tissue obtained from TURP procedures. J Urol 2000;163:613-5.

Miller CL, Diglisic S, Leister F, Webster M, Yolken RH. Evaluating RNA status for RT-PCR in extracts of postmortem human brain tissue. Biotechniques 2004;36:628-33.

Mueller O, Lightfoot S, Schroeder A. RNA integrity number (RIN)—standardization of RNA quality control. Agilent Application Note, Publication Number 5989-1165EN; 2004.

Murakami H, Liotta L, Star RA. IF-LCM: laser capture microdissection of immunofluorescently defined cells for mRNA analysis rapid communication. Kidney Int 2000;58:1346-53.

Mutsuga N, Shahar T, Verbalis JG, Brownstein MJ, Xiang CC, Bonner RF, et al. Selective gene expression in magnocellular neurons in rat supraoptic nucleus. J Neurosci 2004;24:7174-85.

Pardue S, Zimmerman AL, Morrison-Bogorad M. Selective postmortem degradation of inducible heat shock protein 70 (hsp70) mRNAs in rat brain. Cell Mol Neurobiol 1994;14:341-57.

Pearson WR, Wood T, Zhang Z, Miller W. Comparison of DNA sequences with protein sequences. Genomics 1997;46:24-36.

Piper M, Holt C. RNA translation in axons. Annu Rev Cell Dev Biol 2004;20:505-23.

Prosniak M, Zborek A, Scott GS, Roy A, Phares TW, Koprowski H, et al. Differential expression of growth factors at the cellular level in virusinfected brain. Proc Natl Acad Sci USA 2003;100:6765-70.

Robbins TW, Everitt BJ, Ryan CN, Marston HM, Jones GH, Page KJ. Comparative effects of quisqualic and ibotenic acid-induced lesions of the substantia innominata and globus pallidus on the acquisition of a conditional visual discrimination: differential effects on cholinergic mechanisms. Neuroscience 1989;28:337-52.

Roehrl MH, Becker KF, Becker I, Hofler H. Efficiency of single-cell polymerase chain reaction from stained histologic slides and integrity of DNA in archival tissue. Diagn Mol Pathol 1997;6:292-7.

Salzer JL, Holmes WP, Colman DR. The amino acid sequences of the myelin-associated glycoproteins: homology to the immunoglobulin gene superfamily. J Cell Biol 1987;104:957-65.

Sambrook J, Russell DW. Extraction, purification, and anlysis of mRNA from eukaryotic cells. Molecular cloning. Cold Spring Harbor, New York: Cold Spring Harbor Laboratory Press; 2001. p. 7.1-94. 
Schachner M, Bartsch U. Multiple functions of the myelin-associated glycoprotein MAG (siglec-4a) in formation and maintenance of myelin. Glia 2000;29:154-65.

Schmechel D, Marangos PJ, Brightman M. Neurone-specific enolase is a molecular marker for peripheral and central neuroendocrine cells. Nature 1978a;276:834-6.

Schmechel D, Marangos PJ, Zis AP, Brightman M, Goodwin FK. Brain endolases as specific markers of neuronal and glial cells. Science 1978b;199:313-5.

Shi X, Kleeff J, Zhu ZW, Schmied B, Tang WH, Zimmermann A, et al. Geneexpression analysis of single cells-nested polymerase chain reaction after laser microdissection. World J Gastroenterol 2003;9:1337-41.

Sotelo-Silveira JR, Calliari A, Kun A, Benech JC, Sanguinetti C, Chalar C, et al. Neurofilament mRNAs are present and translated in the normal and severed sciatic nerve. J Neurosci Res 2000;62:65-74.

Stoffel W, Hillen H, Giersiefen H. Structure and molecular arrangement of proteolipid protein of central nervous system myelin. Proc Natl Acad Sci USA $1984 ; 81: 5012-6$.
Tomita H, Vawter M, Walsh D, Evans S, Choudary P, Li J, et al. Effect of agonal and postmortem factors on gene expression profile: quality control in microarray analyses of postmortem human brain. Biol Psychiatry 2004;55:346-52.

Torres-Munoz J, Stockton P, Tacoronte N, Roberts B, Maronpot RR, Petito CK. Detection of HIV-1 gene sequences in hippocampal neurons isolated from postmortem AIDS brains by laser capture microdissection. J Neuropathol Exp Neurol 2001;60:885-92.

Vincent VAM, DeVoss JJ, Ryan HS, Murphy Jr GM. Analysis of neuronal gene expression with laser capture microdissection. J Neurosci Res 2002;69:578-86.

Ye P, Bagnell R, D'Ercole AJ. Mouse NG2+ oligodendrocyte precursors express mRNA for proteolipid protein but not its DM-20 variant: a study of laser microdissection-captured NG2+ cells. J Neurosci 2003;23:4401-5.

Zuker M. Mfold web server for nucleic acid bcing and hybridization prediction. Nucleic Acids Res 2003;31:3406-15. 